Notre Dame Law School

NDLScholarship

Journal Articles

Publications

2002

\title{
International Remedies in National Criminal Cases: ICJ Judgment in Germany v. United States
}

Douglass Cassel

Notre Dame Law School, doug.cassel@nd.edu

Follow this and additional works at: https://scholarship.law.nd.edu/law_faculty_scholarship

Part of the International Law Commons

\section{Recommended Citation}

Douglass Cassel, International Remedies in National Criminal Cases: ICJ Judgment in Germany v. United States, 15 Leiden J. Int'1 L. 69 (2002).

Available at: https://scholarship.law.nd.edu/law_faculty_scholarship/839

This Article is brought to you for free and open access by the Publications at NDLScholarship. It has been accepted for inclusion in Journal Articles by an authorized administrator of NDLScholarship. For more information, please contact lawdr@nd.edu. 


\title{
HAGUE INTERNATIONAL TRIBUNALS
}

\section{International Remedies in National Criminal Cases: ICJ Judgment in Germany v. United States}

\author{
Douglass Cassel*
}

Keywords: International Court of Justice; LaGrand case; United States; Vienna Convention on Consular Relations.

\begin{abstract}
In Germany v. United States (2001), the International Court of Justice ruled that the Vienna Convention on Consular Relations confers judicially enforceable rights on foreign nationals detained for prolonged periods or sentenced to severe penalties without notice of their right to communicate with their consulates. The Court also ruled that states which fail to give timely notice cannot later invoke procedural default to bar individuals from judicial relief. However, the Court did not clearly address other issues, such as requiring individuals to show prejudice to the outcome of the trial, or denial of certain remedies for Convention violations, which may effectively foreclose relief.
\end{abstract}

\section{The Judgment And Its Impact in a Nutshell}

In deciding the merits of Germany v. United States, ${ }^{1}$ the International Court of Justice ('ICJ') for the first time intervened definitively, albeit partially, in domestic criminal proceedings. ${ }^{2}$ The Court ruled that the Vienna

* Director, Center for International Human Rights, Northwestern University School of Law, Chicago.

The author is counsel for the Consul General of the Republic of Poland in the case of People v. Madej, 193 Ill.2d 395 (IIl.S.Ct. 2000), cert. denied, 121 S.Ct. 2262, rehearing in light of Germany v. US denied, __ U.S. _ (2001), motion for review in light of Germany v. US denied, __ Ill.2d _ (2001). He was also counsel for two amici curiae before the Inter-American Court of Human Rights in the proceedings on Advisory Opinion OC-16.

1. Case concerning the Vienna Convention on Consular Relations (Germany v. United States of America), No. 104, Judgment, 27 June 2001 ('LaGrand case') (hereinafter 'Judgment'). This and other ICJ documents cited herein are accessible at http://www.icj-cij.org. For comment on the provisional measures stage of the case and background on the death penalty and foreign nationals in the United States, see D. Cassel, Judicial Remedies for Treaty Violations in Criminal Cases: Consular Rights of Foreign Nationals in United States Death Penalty Cases, 12 LJIL 851 (1999) (quoted by Germany before the ICJ, Verbatim Record, 13 November 2000, CR 2000/26, M. Paulus, para. 75).

2. In two previous instances, including an earlier phase of this case, the ICJ indicated provisional measures directing the US not to execute foreign nationals until the ICJ could rule on the merits of claims brought by their governments challenging violations of consular rights under the Convention. Paraguay $v$. US, Request for the Indication of Provisional Measures, Order of 9 April 1998; Germany $v$. US, Request for the Indication of Provisional Measures, Order of 3 March 1999. 
Convention on Consular Relations ${ }^{3}$ confers judicially enforceable rights on foreign nationals detained for prolonged periods or sentenced to severe penalties without being given prompt notice of their right to communicate with their consulates. It further ruled that state parties to the Convention which fail to give prompt notice may not later invoke procedural default to bar foreign nationals from judicial relief. The ICJ thus rejected some but not all of the grounds upon which US courts have denied relief for violations of consular rights. ${ }^{4}$

The case was brought before the ICJ in 1999. Germany sued the US on behalf of itself and its national, Walter LaGrand, who had been convicted of murder and sentenced to death and was about to be executed by the state of Arizona. ${ }^{5}$ Along with his brother, executed days earlier, Walter had not been timely notified of his consular rights. The brothers finally learned of their consular rights 10 years after their arrest and attempted to raise the violations in court. However, US judges ruled that they were procedurally barred for not raising them earlier. ${ }^{6}$

Claiming that it learned only recently that Arizona officials had known since early on that the LaGrands were German nationals, ${ }^{7}$ Germany asked for and got an ICJ order indicating provisional measures directing the US to "take all measures at its disposal to ensure that Walter LaGrand is not

3. 1963 Vienna Convention on Consular Relations, 21 UST 77, TIAS No. 6820, 596 UNTS 261 (hereinafter 'Convention').

4. Formally the ICJ's decision "has no binding force except between the parties and in respect of that particular case," ICJ Statute, Art. 59. But in this case, responding to Germany's request for assurances, the ICJ ordered the US to afford judicial relief to German nationals in certain future cases. Judgment, para. 128(7). Under Art. 94 of the United Nations Charter, the US "undertakes to comply" with ICJ decisions "in any case to which it is a party." As a treaty of the US, the UN Charter is also the "supreme law of the land" for purposes of domestic law. United States Constitution, Art. VI.

At least one judge expects the US to afford the same relief to foreign nationals from countries other than Germany. In a separate Declaration, President Guillaume noted that "subparapraph (7) does not address the position of nationals of other countries [...]. However, in order to avoid any ambiguity, it should be made clear that there can be no question of applying an a contrario interpretation to this paragraph." Declaration of President Guillaume. The majority of the Court likely agrees, even if it does not say so explicitly. (President Guillaume's separate reference to "individuals sentenced to penalties that are not of a severe nature" is discussed in note 93, infra.)

5. For a summary of the facts and US proceedings, see Cassel, supra note 1, at 868-870.

6. Judgment, paras. 23,28 and 29.

7. Judge Buergenthal expressed "serious doubts about the legitimacy" of this claim. Adding that even "assuming that Germany did not actually know these facts, it certainly had no excuse for not knowing them," he dissented from the admissibility of Germany's claim for breach of the provisional measures order. Dissenting Opinion of Judge Buergenthal, para. 12. In his view, Germany "had no good reason for not bringing its request for provisional measures to the Court at least a year or two earlier, if not much earlier." Id. para. 23. Germany's "litigation strategy" (id.) "amounted to procedural misconduct prejudicial to the interests of the United States as a party [...]," rendering its claim inadmissible. Id., at para. 24.

While the Court nonetheless found Germany's claim admissible, it agreed that Germany "may be criticized for the manner in which these proceedings were filed and for their timing." Judgment, para. 57. 
executed pending the final decision in these proceedings [...]." ${ }^{\prime 8}$ When Walter LaGrand was then executed anyway, ${ }^{9}$ Germany proceeded with its case on the merits before the ICJ.

Germany presented three claims of rights and remedies under the Convention. It asked the Court to rule that the US failure to notify LaGrand of his consular rights violated the rights of both Germany and its national under Article 36.1 (submission 1). ${ }^{10}$ It further claimed that by invoking the procedural default rule after failing timely to notify LaGrand of his consular rights, the US violated Article 36.2 (submission 2). ${ }^{11}$ As reparation, Germany asked the ICJ to order the US to provide several assurances: not to repeat its violations, to ensure effective exercise of consular rights, and in the event of future violations involving the death penalty, to provide for effective judicial review and remedies for criminal convictions impaired by the violations (submission 4). ${ }^{12}$

The US opposed most of Germany's claims. It also objected that Germany was in effect asking the ICJ to become an ultimate court of criminal appeals. Nonetheless the Court ruled:

1. Individual rights: The Convention confers rights on individuals to be notified of their right to communicate with their consulates. ${ }^{13}$

2. Judicial remedies: Where individuals not so notified are then detained for a prolonged period, or convicted of crimes and sentenced to severe penalties, remedies are not limited to diplomatic apologies and undertakings, but must include domestic judicial remedies on behalf of individuals. By means of their own choosing, states must allow review and reconsideration of such convictions and sentences to take account of the violations. ${ }^{14}$

3. Procedural defaults: Where a state fails in its duty to notify a detained foreign national of his right to consular communication, it may not later invoke procedural default to bar the individual from judicial relief. ${ }^{15}$

The ICJ ruling thus rejects at least two grounds on which foreign nationals have sometimes been denied judicial relief in the US - the mistaken view that the Convention does not confer judicially enforceable indi-

8. Order, 3 March 1999, supra note 4, at para. 29(I).

9. Judgment, para. 34.

10. Judgment, para. 12(1). Submission 1 also asserted a violation of Art. 5 of the Convention, which the ICJ found unnecessary to address. Id., at paras. 12(1), 73.

11. Id., at para. $12(2)$.

12. Id., at para. $12(4)$

13. Id., at paras. $77,128(3)$.

14. Id., at paras. $123,125,128$; see note 59 infra.

15. Id., at paras. $91,128(4)$. 
vidual rights, ${ }^{16}$ and the use of procedural default to bar late claims presented by individuals who were not timely notified of their consular rights. ${ }^{17}$

However, its practical impact in the US will probably be quite limited, because it leaves open other grounds. Many US courts have denied relief on the ground that particular remedies or remedial theories, such as suppression of incriminating statements, ${ }^{18}$ dismissal of indictments,,${ }^{19}$ or relief from ineffective assistance of counsel, ${ }^{20}$ are unavailable under the Convention. Others - or often the same courts, relying on multiple grounds - deny remedies unless violations are shown to prejudice the outcome of

16. US v. Li, 206 F.3d 56, 66 (1st Cir.) (en banc) (Convention creates no judicially enforceable individual rights), cert. denied, 121 S.Ct. 379 (2000); accord, US v. Emuegbunam, 2001 U.S. App. LEXIS 21509, 19-20 (6th Cir. 2001); State v. Martinez-Rodriguez, 2001 N.M. LEXIS 331, at 14-17 (New Mexico Supreme Court); see also US v. Bustos de la Pava, 268 F.2d 157, 163-165 (2d Cir. 2001) (strongly suggesting the same conclusion).

17. E.g., Breard v. Greene, 523 U.S. 371, 140 L.Ed.2d 529, 537 (1998); LaGrand v. Stewart, 170 F.3d 1158, 1161 (9th Cir. 1999); LaGrand v. Stewart, 133 F.3d 1253 (9th Cir. 1998); Gibson v. US, 2001 U.S. Dist. LEXIS 16756, 1 (S.D.N.Y. 2001); Vasquez v. State, 2001 Del. LEXIS 467, 2-3 (S.Ct.Del. 2001); People v. Madej, 193 Ill.2d 395 (Ill.S.Ct. 2000), cert. denied, 121 S.Ct. 2262, rehearing in light of Germany v. US denied, __ U.S. (2001), motion for review in light of Germany v. US denied, _ Ill.2d _- (2001); State v. Hernandez, 2001 Minn. App. LEXIS 1287, 15 (Ct.App.Minn. 2001); State v. GomezSilva, 2001 Ohio App. LEXIS 5334, 9-12 (2001); State v. Ruvalcaba, 2001 Ohio App. LEXIS 5371, at 4-7 (2001); Cassel, supra note 1, at n. 112 (citing other cases on procedural default).

18. E.g., US v. Li, supra note 16, 206 F.3d, at 66; US v. Cowo, 2001 U.S. App. LEXIS 24963, 2 (1st Cir. 2001); US v. Jimenez-Nava, 243 F.3d 192, 198-199 (5th Cir. 2001); US v. Page, 232 F.3d 536, 541 (6th Cir. 2000), cert. denied, 121 S.Ct. 2202 (2001); US v. ChaparroAlcantara, 226 F.3d 616, 622 (7th Cir.), cert. denied, 121 S.Ct. 599 (2000); US v. Lawal, 231 F.3d 1045, 1048 (7th Cir. 2000), cert. denied, 121 S.Ct. 1165 (2001); US v. Carrillo, 269 F.3d 761, 771 (7th Cir. 2001); US v. Felix-Felix, 2001 U.S. App. LEXIS 27213, 16 (7th Cir. 2001); US $v$. Lombera-Camorlinga, 206 F.3d 882, 885 (9th Cir.) (en banc), cert. denied, 121 S.Ct. 481 (2000); US v. Chanthadara, 230 F.3d 1237, 1255-1256 (10th Cir. 2000); US v. Cordoba-Mosquera, 212 F.3d 1194, 1196 (11th Cir. 2000), cert. denied, 121 S.Ct. 893 (2001); US v. Bin Laden, 132 F. Supp.2d 168, 196 (S.D.N.Y. 2001), reaffirmed, 2001 U.S. Dist. LEXIS 15484, at 28 (2001); State v. Martinez-Rodriguez, supra note 16, at 21-22; State v. Gomez-Silva, supra note 17; State v. Tuck, 2001 Ohio App. 5851, 5 (2001). In one recent case, US $v$. Minjares-Alvarez, 2001 U.S. App. LEXIS 16867, 15 (2001), decided one month after the ICJ ruled in Germany $v$. US, the court noted, "It does not appear that the [ICJ] considered the applicability of the exclusionary rule to violations of the Vienna Convention [...]." Id., at 18 .

19. E.g., US v. Cowo, supra note 18, at 2; US v. Bustos de la Pava, supra note 16, at 165-166; US $v$. Emuegbunam, supra note 16, at 19-20; US v. Page, supra note 18, 232 F.3d, at 540; US $v$. Chaparro-Alcantara, supra note 18, 226 F.3d, at 618.

20. US $v$. Bustos de la Pava, supra note 16, at 163-166; Gibson $v$. US, supra note 17, at 3; see also Helassage v. US, 2001 U.S. Dist. LEXIS 17951, 10-11 (S.D.N.Y. 2001) (ordering evidentiary hearing on claim of ineffective assistance of counsel). 
the trial, ${ }^{21}$ an issue not clearly resolved by the ICJ ruling. ${ }^{22}$ Even if US courts fully comply with the ICJ ruling, then, it may be that few foreign nationals will obtain judicial relief.

This potential lack of practical impact results not from undue timidity or lack of foresight by the ICJ, but from the limits of the case before it, which turned on procedural default. ${ }^{23}$ The Court appropriately decided the questions necessary to resolve that case. Had it addressed issues raised by other cases, it would have been open to the charge of judicial overreaching.

Might future cases give the ICJ an opportunity to provide further clarification? Having now decided that the choice of appropriate judicial remedies must be left to states, the ICJ will not likely second guess US court rulings that particular remedies are unavailable to enforce the Convention in the US. Likewise, conscious of its limited role in domestic criminal cases, and assuming that it has not already done so, ${ }^{24}$ the ICJ may be reluctant to delve into the question of whether or how judicial relief might be made to depend on a showing of prejudice. On the other hand, if it can be shown that no effective judicial remedy is available, or that domestic law tests for prejudice are so strict as to render illusory any real prospect of judicial remedy, the ICJ might well decide that its proper role of interpreting international law requires further intervention, in the event a case is brought before it. (See further discussion in Sections 3.1 and 3.2, infra.)

In addition to interpreting the Convention, the Judgment in Germany v. $U S$ makes significant ancillary rulings beyond the scope of this comment:

- Most important, it rules that ICJ orders of provisional measures are binding, ${ }^{25}$ thereby settling a long-running dispute. ${ }^{26}$

- It clarifies that where a treaty conferring individual rights has a general jurisdictional clause, the ICJ likewise has jurisdiction over

21. E.g., US v. Minjares-Alvarez, supra note 18, at 19-20; US v. Cordoba-Mosquera, supra note 18, 212 F.3d, at 1196; US v. Chanthadara, supra note 18, at 1256; US v. Bin Laden, supra note 18, 132 F. Supp.2d, at 195-196; Gibson v. US, supra note 17, at 2; Vasquez v. State, supra note 17, at 2-3; Darling $v$. State, 2001 Fla. LEXIS 6, 52 (S.Ct.Fla. 2002) (not final pending expiration of time to petition for rehearing); State $v$. Lopez, 2001 Iowa Sup. LEXIS 144, at 20-22 (S.Ct.Iowa 2001); State $v$. Martinez-Rodriguez, supra note 16, at 23-26; State v. Issa, 93 Ohio St.3d 49, 57 (S.Ct.Ohio 2001); State v. Hernandez, supra note 17; see also cases cited in Cassel, supra note 1, at n. 114.

22. There is some ambiguity in the Judgment on this point. See notes 82-84, infra and accompanying text.

23. Judgment, paras. 23, 28 and 29.

24. See supra note 22 .

25. Judgment, at paras. 109, 128(5). See also para. 12(3) (Germany's submission 3) and paras. 92-116 and $128(2)(\mathrm{c})$.

26. Compare Brief for the US as Amicus Curiae, Paraguay v. Gilmore, 1997 US Briefs 1390, at 49-51, with S.A. Shank \& J. Quigley, Obligations to Foreign Nationals Accused of Crime in the United States: A Failure of Enforcement, 9 Criminal Law Forum 99, at 113-117 (1999). 
state claims on behalf of nationals under the customary law of diplomatic protection. ${ }^{27}$

- It confirms that where the ICJ has jurisdiction over a dispute, it also has jurisdiction over appropriate remedies. ${ }^{28}$

\section{ICJ RULing ON CONVENTION ISSUES}

\subsection{Individual right to notice of consular rights}

Germany alleged a violation of its rights and those of its national to notice of consular rights. Article 36.1(b) of the Convention requires authorities detaining a foreign national to "inform the person concerned without delay of his rights under this subparagraph." Those rights include the right, if he so requests, to inform consular officials without delay of his detention, and the right to have any communication forwarded to the consulate without delay. ${ }^{29}$ As consequence of the failure of notice, Germany further alleged violations of its rights to render consular assistance. ${ }^{30}$

The US did not dispute its failure to notify LaGrand of his consular rights. ${ }^{31}$ Nor did it contest jurisdiction over Germany's claim in its own right for violation of consular notice. ${ }^{32}$

However, the US otherwise contested jurisdiction, admissibility and the merits. It objected to jurisdiction over Germany's claim for diplomatic protection of its national, as well as over the alleged violations of the right to render consular assistance. ${ }^{33}$ It objected to admissibility, on the ground that LaGrand did not exhaust local remedies, because he did not raise the denial of notice of his consular rights at trial. Attributing that failure to his defense counsel, whose failure was in turn imputable to the client, the US argued that it could not be held accountable for errors by defense counsel. ${ }^{34}$ It further objected to admissibility on the ground that Germany sought to impose a standard on the US that it does not itself meet. ${ }^{35}$

On the merits, the US contested the violations of Germany's rights of consular assistance,$^{36}$ and argued that Article 36 confers no rights on individuals, only on states. ${ }^{37}$

27. Judgment, para. 42 .

28. Id., at para. 48 .

29. Art. 36.1 of the Convention is quoted in full in para. 37 of the Judgment. See, generally, Cassel, supra note 1 , at $855-857$.

30. Judgment, para. 38. Consular officers have the rights to communicate with and have access to their detained nationals (Art. 36.1(a)), as well as to visit, converse and correspond with them and arrange for their legal representation (Art. 36.1(c)).

31. Judgment, para. 67 .

32. Id., at para. 39 .

33. Id., at para. 40.

34. Id., at para. 58.

35. Id., at para. 61.

36. Id., at para. 69.

37. Id., at para. 76 . 
The Court rejected all these objections. The disputes over denial of consular assistance and individual rights gave the ICJ jurisdiction under the Optional Protocol to the Convention..$^{38}$ The US could not rely on the defense lawyer's failure, "as it was the United States itself which had failed to carry out its obligation under the Convention to inform the LaGrand brothers." 39 Moreover, the evidence did not show that in cases of severe penalties Germany failed to meet its asserted standards. ${ }^{40}$

On the merits, the Court found that since Germany did not learn of the detention until ten years later, the failure of notice also had the consequence of impairing its right to render consular assistance ${ }^{41}$ Further, the Court found that Article 36.1 "creates individual rights." ${ }^{2}$ The clear language of the text sufficed to reach that conclusion: Article 36.1(b) mandates that a detained foreign national be notified of "his rights," and is followed by a proviso that consular assistance may not be rendered if the detainee "expressly opposes such action." 43 The Convention's plain meaning is to confer individual rights.

\subsection{Procedural default rules}

Germany argued that by applying domestic rules of procedural default after failing to notify LaGrand of his rights, the US violated its duty to Germany under Article 36.2 to give "full effect" to the purposes of Article 36 rights. ${ }^{44}$

The US did not contest jurisdiction over the procedural default claim, but objected to its admissibility. Germany was asking the ICJ to review alleged errors of domestic law and judgment by US judges, and thereby

38. Id., at para. 42. Art. I of the Optional Protocol Concerning Compulsory Settlement of Disputes to the Vienna Convention on Consular Relations of 24 April 1963 states in part, "Disputes arising out of the interpretation or application of the Convention shall lie within the compulsory jurisdiction of the International Court of Justice [...]."

Judge Parra-Aranguren dissented from the finding of jurisdiction over Art. 36.1(b) on the ground that there was no dispute between the parties. Separate Opinion of Judge ParraAranguren, paras. 4-10. Judge Oda dissented on the same ground, Dissenting Opinion of Judge Oda, paras. 19-21, and also objected to the admissibility of all Germany's submissions, on the ground that the Court should have ruled only on the admissibility of the original application, id., at para. 22 .

39. Judgment, para. 60.

40. Id., at para. 63. See discussion at note 96, infra and accompanying text.

41. Id., at para. 73 .

42. Id., at para. 77.

43. Art. 36.1(c). Judge Oda dissented from the finding of individual rights. Dissenting Opinion of Judge Oda, paras. 23-24. Vice-President Shi did not formally dissent, but agreed with the US that Art. 36.1(b) creates no "independent" individual rights, but only rights "derivative" of the state's rights. Separate Opinion of Vice-President Shi, paras. 2-15.

44. Judgment, para. 79. Art. 36.2 provides,

The rights referred to in paragraph 1 of this Article shall be exercised in conformity with the laws and regulations of the receiving State, subject to the proviso, however, that the said laws and regulations must enable full effect to be given to the purposes for which the rights accorded under this Article are intended. 
to convert itself into an "ultimate court of appeal in national criminal proceedings." 45 The Court answered, however, that it was asked "to do no more than apply the relevant rules of international law." ${ }^{46}$

On the merits, the US argued that since the Convention "does not require States Party to create a national law remedy" for individuals, there could be no violation in defaulting this non-existent remedy. ${ }^{47}$ National rules of criminal procedure were simply not covered by Article 36.2, meant to address only the timing and manner of consular communications and visits. $^{48}$

The Court answered that since Article 36.1 protects individual as well as state rights, the cross reference to these rights in Article 36.2 likewise covers the individual rights. ${ }^{49}$ The problem in this case was not the procedural default rule per se, but its application to bar a claim that consular notice was not provided promptly, thus preventing the LaGrands from seeking and Germany from rendering consular assistance. ${ }^{50}$ The procedural bar prevented US judges from "attaching any legal significance to the fact, inter alia," that the failure of notice "prevented Germany, in timely fashion, from retaining private counsel for them and otherwise assisting in their defense as provided for by the Convention." It thus prevented "full effect" from being given to the purposes of Article 36 rights. ${ }^{51}$

\subsection{Judicial remedies for violations}

Germany asked the Court to order the US to give three assurances: not to repeat its violations; to ensure effective exercise of consular rights; and to provide "effective review of and remedies for criminal convictions" impaired by any violations in death penalty cases. ${ }^{52}$

The US objected to the Court's jurisdiction over assurances and guarantees, arguing that they are "conceptually distinct from reparation," unprecedented, and exceed the ICJ's remedial power. ${ }^{53}$ The Court answered

45. Judgment, para. 50. The US' objection that Germany did not itself meet the proposed standard, discussed above, applied to Germany's "submissions." Id., at para. 61.

46. Id., at para. 52 .

47. Id., at para. 85 .

48. Id., at para. 86 .

49. Id., at para. 89. Since Vice-President Shi did not find independent individual rights in Art. 36.1 , see supra note 43 , he likewise did not consider them to be included in the "rights" referred to in Art. 36.2. Separate Opinion of Vice-President Shi, para. 16. Again, however, he did not formally dissent.

50. Judgment, para. 90 .

51. Id., at para. 91. Judge Oda dissented from this ruling. Dissenting Opinion of Judge Oda, paras. 26-27. Although not formally dissenting, Judge Koroma disagreed that the application of the procedural default rule violated Art. 36.2. Separate Opinion of Judge Koroma, para. 5.

52. Judgment, para. 117.

53. Id., at paras. 46, 119. In response to Germany's request for assurances, the US raised no new arguments regarding admissibility, only those discussed supra regarding an ultimate court of criminal appeals and Germany's alleged failure to meet its own standards. 
that it has jurisdiction to resolve a "dispute regarding the appropriate remedies" that arises out of interpretation or application of the Convention. Where jurisdiction exists over a matter, no separate basis of jurisdiction is required to consider the appropriate remedies. ${ }^{54}$

On the merits, the US repeated these objections, adding that it could not possibly meet Germany's demand that it "never again fail" to give notice. If the Court were to find a violation resulting from application of the procedural default rule, "it should limit that judgment to the particular case of the LaGrands" and not address future cases. ${ }^{55}$

The Court found that no state could guarantee that it would never again fail to give notice, and that sufficient assurance of non-repetition was already provided by the "substantial measures" included in the "vast and detailed programme" undertaken by the US to inform and train law enforcement officers about consular rights. ${ }^{56}$

On the other hand, the Court made clear that in this or any other case - including future cases - where foreign nationals are not timely notified of their consular rights and are "subjected to prolonged imprisonment or sentenced to severe penalties," diplomatic apologies are not sufficient. ${ }^{57}$ In the event of a failure to give consular notice in a case involving a criminal conviction and sentence to severe penalties,

it would be incumbent upon the United States to allow the review and reconsideration of the conviction and sentence by taking account of the violation of the rights set forth in the Convention. ${ }^{58}$

How should that be done? The Court answered, "This obligation can be carried out in various ways. The choice of means must be left to the United States." 59

54. Id., at para. 48.

55. Id., at para. 119

56. Id., at paras. 121,123 and 124 .

57. Id., at paras. 123, 125; for the meaning of "severe penalties," see note 96, infra and accompanying text.

58. Id., at para. 125. Judge Oda dissented, on the ground that he was "utterly at a loss as to what the Court intends to say in this subparagraph." Dissenting Opinion of Judge Oda, para. 37.

59. Judgment, para. 125. Because the Court did not expressly state that "review and reconsideration" must be judicial, some might suggest that judicial remedies are not required and that executive clemency could suffice. Such a view is misplaced. First, the Court's rejection of the application of procedural default - a doctrine which precludes only judicial remedies - would be pointless if judicial remedies were not otherwise available. Second, executive clemency is not generally an adequate remedy for failures of consular notification. While clemency may relieve an individual from serving the sentence, it cannot undo the underlying conviction. $C f$. The Queen $v$. Peter Hughes, Privy Council Appeal No. 91 of 2001, Judgment of 11 March 2002 (on appeal from the Eastern Caribbean Court of Appeal (Saint Lucia)), para. 13. ("While the act of clemency is, indeed, to be seen as part of the whole constitutional process of conviction, sentence and the carrying out of the sentence, it is an executive act and cannot be a substitute for the judicial determination of the appropriate sentence.") Of course, where a failure of consular notice taints only the punishment and not the underlying conviction, clemency could be a sufficient remedy. 


\section{Liklely IMPaCt In The United States}

The issues addressed by the ICJ have not yet been definitively confronted by the US Supreme Court, whose only opinions to date have been brief, hurried denials of requests for review and for stays. ${ }^{60}$ They have been addressed by numerous lower courts in the US, ${ }^{61}$ but without the benefit of guidance either from the Supreme Court or - until its recent Judgment - from the ICJ.

One might view this unsettled state of affairs as an open door for international law to enter into US domestic jurisprudence. ${ }^{62}$ It may indeed prove to be a doctrinal portal. But for several reasons, the ICJ Judgment will likely have little direct, practical impact on the outcome of cases involving Convention violations in the US.

One reason is that two of its most important rulings - that the Convention confers individual rights, requiring judicial remedies in serious criminal cases - have already been effectively bypassed by most US courts. Although typically aware of the State Department claim that the Convention confers no justiciable individual rights, the lower US courts read the explicit language of individual rights in Article 36.1(b). They also read the Supreme Court's brief opinion in Breard, which denied relief on grounds of procedural default, but also acknowledged that the Convention "arguably confers on an individual the right to seek consular assistance following arrest." ${ }^{\prime 3}$ As noted by one recent federal court of appeals decision, "[T]he Supreme Court has left open the question of whether the Vienna Convention creates an individual right enforceable by the federal courts." 64

In consequence, most US courts hedge their bets. They "assume, without deciding" that the Convention creates individually enforceable rights, but "then hold that the requested remedy is inappropriate or the defendant did not prove he was prejudiced by the alleged Article 36 violation." 65

Moreover, as this suggests, most US courts rely on multiple grounds to deny relief, usually including one or more grounds not addressed by the ICJ. For example, noting that the ICJ did not address exclusion of evidence as a remedy, one recent federal court of appeals decision ruled that suppression of a statement given by the defendant is not an appropriate

60. Breard v. Greene, 523 U.S. 371 (1998); Germany v. US et al., 119 S.Ct. 1016 (1999); LaGrand v. Arizona, 119 S.Ct. 1137 (1999); see discussion in Cassel, supra note 1, at $867-870$.

61. See supra notes 16-21.

62. See, generally, H. Hongju Koh, Review Essay: Why Do Nations Obey International Law?, 106 Yale L. J. 2599 (1997).

63. Breard v. Greene, supra note 60 , at 376.

64. US $v$. Emuegbunam, supra note 16, at 18.

65. State $v$. Lopez, supra note 21, at 17, quoting Ledezma $v$. State, 626 N.W.2d 134, 151 (Iowa 2001). For example, many of the cases cited in supra note 18 assumed without deciding that the Convention creates individually enforceable rights. 
remedy, and even if so, the statement did not prejudice the outcome of his trial. ${ }^{66}$

Two issues left open by the ICJ may well become favored escape hatches by which US courts evade any practical consequences. One is the ICJ ruling that the "choice of means" must be left to the US. The other is its arguable - albeit ambiguous - leaving open of the question of whether any judicial remedy can be conditioned on a showing of prejudice. (Both are further discussed in Sections 3.1 and 3.2, infra.)

A final factor is the degree of respect that US courts are likely to show to the Judgment of the ICJ. While it is far too soon to tell, in the first six months following the decision in Germany v. US, of 20 reported US court judgments expressly addressing the Convention, only three mentioned the ICJ Judgment, ${ }^{67}$ and none relied on it, except a dissenting judge in one case. ${ }^{68}$ In rulings probably based principally on their unusual procedural postures, the US Supreme Court refused to grant rehearing based on the ICJ Judgment of an earlier denial of review, ${ }^{69}$ and the Illinois Supreme Court likewise declined to reconsider, in light of the ICJ's ruling, an earlier ruling of procedural default. ${ }^{70}$ On the other hand, at least one lower court recently stayed an execution of a foreign national pending further review, reportedly explaining, "This court has before it a unique and serious matter involving novel legal issues and international law." 71

Even if foreign nationals detained in the US without notice of consular rights should not expect much practical relief as a result of the ICJ

66. US $v$. Minjares-Alvarez, supra note 18, at 15-20.

67. The three were US $v$. Minjares-Alvarez, id.; State $v$. Lopez, supra note 21; and State $v$. Issa, supra note 21, 752 N.E.2d 904, 931, 933 (Lundberg Stratton, J., dissenting). In several of the 20 cases, argument and even drafting may have been completed prior to announcement of the ICJ Judgment. See cases cited in supra notes 16-21. Another reported decision on consular rights has not yet reached final judgment, but similarly does not mention the ICJ Decision. Helassage $v$. US, supra note 20 , at 10-11.

68. State $v$. Issa, supra note 67 (Lundberg Stratton, J., dissenting).

69. Consul General of Poland et al. v. State, 121 S.Ct. 2262 (denying certiorari), rehearing denied, US (1 October 2001). Because the Supreme Court rarely, if ever grants rehearing of decisions declining review, little if any substantive weight should be accorded to this denial. Nonetheless, had the Court wanted a vehicle to consider the ICJ Judgment, this case gave it an opportunity because the lower court ruling, based on procedural default, conflicts with the ICJ Judgment. The present author represents the Consul General in the case.

70. Consul General v. Illinois, no. 92152, ___ Ill.2d ___ (2001) (denying petition for further review based on ICJ Judgment in Germany $v$. US). Here, too, the normal period for rehearing had long since expired. The Illinois Court's ruling may thus have been based more on the extremely unusual procedural posture of the request than on any view of the merits.

71. J. Greiner, Mexican National Granted Indefinite Stay of Execution, The Daily Oklahoman, 11 September 2001, accessible in LexisNexis News Library (case of Gerardo Valdez, alleging violation of his consular rights). For prior developments in the case, see Amnesty International, United States of America: A Time for Action-Protecting the Consular Rights of Foreign Nationals Facing the Death Penalty, AI Index AMR 51/106/2001, at 8-10 (August 2001). As of the end of 2001, the stay remained in effect. See B. Hoberock, State's Execution Mark May Stand, The Tulsa World, 17 December 2001, accessible in LexisNexis News Library. 
Judgment, the international and domestic litigation and public attention to consular rights appear to yield two other benefits. One is that compliance with the notice provisions of the Convention, while still seriously deficient, ${ }^{72}$ has improved dramatically in recent years and may be further spurred by the ICJ Judgment. The improved effort by the State Department is discussed in the ICJ Judgment. ${ }^{73}$ In addition, a number of state and local legislatures, courts, prosecutors and police departments have recently adopted laws, regulations and programs to promote compliance. ${ }^{74}$ In a recent opinion, even while declining to rule on a Convention claim, one state Supreme Court nonetheless lectured the bar on consular rights, explaining:

We believe all criminal defense attorneys representing foreign nationals should be made aware of the right to consular access [...], and should advise their clients of this right $[\ldots]$. Consular officials can eliminate false understandings and prevent actions which may result in prejudice $[\ldots .$.$] . Consular access may very well make$ a difference to a foreign national $[\ldots] . .^{75}$

A second benefit may be to enhance international law literacy and sensitivity among US judges. During 2001, for example, courts in the US pub-

72. "All of these efforts [at improved compliance with the Convention] are important and welcome developments. However, the evidence available to Amnesty International indicates that frequent violations of Article 36 rights continue across the USA. Both local and federal law enforcement agents remain largely ignorant or heedless of their binding treaty obligations." Amnesty International, supra note 71, at 7 (footnote omitted).

73. Judgment, para. 121 (60,000 brochures and 400,000 pocket cards distributed to US law enforcement and judicial officers, in addition to training programs). Responding to a question on the US response to the ICJ Judgment in March 2002, State Department Legal Adviser William Howard Taft IV stated,

I'm surprised to hear you say that the United States has, since the ruling of the Court, taken a position contrary to the Court's ruling. [...] The Court has ruled, and we have taken many steps since then and we're continuing to take more, because it is an extremely difficult matter, [...], in a country as big as ours, with as much law enforcement activity as ours, involving as many non-nationals as ours, to be sure that we're doing this right, but the commitment of the government is to abide by the Convention as interpreted by the Court.

In response to a follow-up question about the articulation of this position to US courts, he added,

I'm not sure that there's been a court case where we've actually been asked for our view on that, but where we have been asked, we have advised [...] states which have procedures, we've advised them of the opinion that the Court gave and recommended that they take it into account, and I believe they're doing that.

Annual Meeting of the American Society of International Law, 14 March 2002, Presidential Panel: The Impact of the United States on International Law (author's transcription; audio tape available for ASIL and on file with author).

74. For example, since January 2000 the Texas Attorney General, the City of Chicago police, and the State's Attorney of Cook County, Illinois have all issued directives designed to bring about notification of consular rights. See Amnesty International, supra note 71, at 6-7.

75. Ledezma v. State, 626 N.W.2d 134, 152 (Iowa 2001). 
lished only 167 opinions mentioning "international law"; in the same year they addressed consular rights under the Convention in some 50 cases. $^{76}$ Convention cases often involve extended analysis of international law and reach senior US judges on federal appellate courts and state Supreme Courts. ${ }^{77}$ Following Germany v. US, consular rights litigation may well increase.

Ultimately consular rights cases may contribute to an improved international law culture in US courts. But there is not yet cause for exuberance; to date US courts have used whatever they might have learned about international law to reject nearly all claims based on the Convention. ${ }^{78}$

\subsection{Choice of means}

In requiring review and reconsideration of criminal convictions and sentences in cases of severe penalties, the ICJ left the choice of means to the US. This was consistent with the proper role of an international court, as well as an implicit response to the US rhetoric that any ruling on judicial remedies would transform the ICJ into a global court of criminal appeals.

While thus proper and prudent, leaving the choice of means to national authorities will mean further litigation. Numerous US lower courts have ruled that dismissing indictments, suppressing statements made by foreign nationals not advised of their consular rights, or finding ineffective assistance of counsel where defense lawyers fail to advise their clients of rights to assert claims based on Convention violations, are not appropriate remedies. ${ }^{79}$ If these remedies are excluded, what is left?

Arguably adequate remedies remain: reviewing courts could reverse convictions or sentences, and remand for either a new trial or a new hearing on the punishment. ${ }^{80}$ But what if one or more of these remedies, too, are ruled inappropriate by US courts? Or what if US courts allow them, but set the bar so high for claimants - for example by requiring unrealistic showings of prejudice - that the remedies are effectively unavailable? In

76. Searches by author conducted 4 January 2002, of LEXIS combined federal and state case law for year 2001, using search terms "international law" and "Vienna Convention on Consular Relations."

77. See cases cited in supra notes 16-21.

78. For refreshing exceptions, see Standt $v$. City of New York, 153 F. Supp.2d 417, 422-431 (2001) (denying summary judgment for defense and allowing civil damages suit as remedy for alleged Convention violation); and State $v$. Reyes, 740 A.2d 7, 13-14 (Del. Superior Ct. 1999) (evidence suppressed because failure to advise defendant of consular rights precluded intelligent waiver of Miranda rights), state's leave for appeal denied, 765 A.2d 953 (Del. Supreme Ct. 2000). (The limited precedential value of this Delaware lower court decision may be undermined by the Delaware Supreme Court's later denial of a consular rights notification claim in Vasquez $v$. State, supra note 17, based on lack of prejudice and procedural waiver.) There have also been notable dissenting opinions showing respect for international law. E.g., State $v$. Issa, supra note 21, 752 N.E.2d 904, 931, 933 (Lundberg Stratton, J., dissenting); US v. Li, supra note 16, 206 F.3d, at 72 (Toruella, J., concurring in part and dissenting in part).

79. See supra notes 18-20. 
either event, will the US have given "full effect" to the purposes of consular rights, as required by Article 36.2? Should another case be brought before it, the ICJ may have to revisit the matter.

Even allowing the US wide latitude in its choice of means, questions may nonetheless arise about particular means. For example, is a new trial an adequate remedy, or merely a pointless exercise, in a case where a confession secured in violation of consular rights remains the central proof of guilt? In some such cases, a new trial may be meaningful. It may afford an opportunity through consular assistance to introduce new evidence from the foreign national's home country, to overcome cultural barriers in his communications with his lawyer, or even to secure a more capable or wellfinanced attorney. But in other cases it may not. The adequacy of remedies may have to be determined on a case-by-case basis.

What if police officers deliberately refrain from advising a detained foreign national of his consular rights, or deliberately delay his consular communication, until after they extract a confession? In case of such a wilful violation of consular rights, would the refusal by US courts to suppress the resulting statement give "full effect" to the purposes of consular rights? ${ }^{81}$

If further cases are brought to The Hague (which will depend of course on decisions by governments, not by detained individuals or by the Court), the ICJ will need to strike a delicate balance. Remedial questions like these are similar to the judgment calls and policy questions faced daily by national courts enforcing domestic law rights. To intrude too deeply into them could indeed risk the ICJ's becoming an ultimate court of criminal appeals. On the other hand, for the ICJ to abstain entirely from review of the national choice of means risks allowing nullification of rights guaranteed by international law. In Germany v. US, the Court struck the balance well. The next case (if there is one) may be even more challenging.

80. See, generally, Cassel, supra note 1, at 879-882. There is also the question of judicial remedies for individuals whose consular rights were violated but who were not later convicted or imprisoned. One possibility is civil suits for damages for alleged injuries, including brutality at the hands of police, caused or facilitated by violations of consular rights. US courts disagree on the availability of this remedy. Compare Standt $v$. City of New York, supra note 78 (allowing civil damages suit) with Sorenson $v$. City of New York, 2000 U.S. Dist. LEXIS 15090, at 16 (S.D.N.Y. 2000) (no private action under US civil rights law for violations of consular rights, because "the Vienna Convention, by its terms, does not require that such violation be remedied by money damages").

81. The European Court of Human Rights declined to suppress tainted evidence in Khan $v$. United Kingdom, Judgment of 12 May 2000, final 4 October 2000, App. No. 35394/1997, accessible at http://hudoc.echr.coe.int, and in Schenck $v$. Switzerland, Judgment of 12 July 1988, App. No. 00010862/84, 1991 ECHR (Ser. A) No. 140, accessible at http:// hudoc.echr.coe.int. The questions decided in those cases, however, were different: whether admission of tainted evidence deprived the applicant of a fair trial (Schenck, paras. 46-49 and Khan, paras. 29, 34-40), or of the right to be proved guilty "according to law" (Schenck, paras. 50-52), or of his right to privacy (Schenck, para. 53). In contrast, under the Convention the question would be whether use at trial of evidence obtained by means of violating the Convention fails to give "full effect" to the purposes of consular notification. 


\subsection{Prejudice}

Germany argued that the violations of consular rights prejudiced the LaGrands. Timely consular assistance, it said, could have built a more effective case in mitigation which "likely would have saved" them. The US dismissed this contention as speculative, noting that comparable mitigation evidence was in fact heard. ${ }^{82}$

Because the LaGrands had already been executed, however, this duel was apparently not over whether their convictions should be reversed - it was too late for that - but whether the denial of consular access violated their rights. The ICJ concluded:

It is immaterial for the purposes of the present case whether the LaGrands would have sought consular assistance [...], whether Germany would have rendered such assistance, or whether a different verdict would have been rendered. It is sufficient that the Convention conferred these rights, and that Germany and the LaGrands were in effect prevented by the breach [...] from exercising them, had they so chosen. ${ }^{83}$

While this passage is not free from ambiguity, it appears to mean that prejudice need not be shown to establish a violation, while leaving open the question of whether prejudice must be shown to trigger judicial remedies. ${ }^{84}$

US courts commonly answer this question in the affirmative. When they assume without deciding the availability of judicial remedies, they typically place the burden on the foreign national to show that if notified of his rights, he would have contacted his consul and, if so, the consul would have assisted him and, if so, the assistance would have changed the outcome. ${ }^{85}$ As this author has argued previously, placing the burden on the individual (or anyone) to make such showings is unrealistic; if prejudice is relevant at all, the burden ought to be on the state to demonstrate that there was no credible likelihood of prejudice. ${ }^{86}$ Since the ICJ Judgment

82. Judgment, paras. 71-72.

83. Id., at para. 74 (emphasis added).

84. The passage appears in the section of the Judgment on the merits of Germany's first submission - that the denial of notice violated consular rights. The ambiguity arises from the phrase, "for the purposes of the present case." The Court did not say only, "for the purposes of submission 1." And the "present case" also includes submission 4, which does request assurances of judicial remedies. However, since LaGrand was already executed and Germany did not request rehearing of his conviction or sentence, the "present case" raised no issue of conditioning his rehearing on a showing of prejudice. Moreover, the passage on prejudice is not repeated or referenced in the Court's subsequent discussion of remedies, which leaves the choice of means to national authorities. The passage thus appears to mean only that prejudice need not be shown in order to establish a violation.

85. See cases cited in supra note 21.

86. Cassel, supra note 1, at 882-884. The approach of the German Federal Court of Justice appears to be similar. It holds that it is "sufficient to show that it cannot be excluded that the decision of the court might have been different if the law had been applied properly." Verbatim Record before ICJ, CR 2000/29, argument of M. Kaul, para. 12.ii. 
appears to abstain from this debate, however, there is little reason to expect US courts to reconsider their views.

If the right to consular notice were considered a fundamental or human right, both US and international law suggest grounds to argue that no showing of prejudice would be needed. In US law violations of fundamental rights may suffice to trigger judicial remedies with no showing of prejudice. ${ }^{87}$ It may also be argued that in international law violations of fundamental human rights may per se require remedies. ${ }^{88}$ The InterAmerican Court of Human Rights has held that at least in death penalty cases, consular rights are human rights. ${ }^{89}$ Germany requested the ICJ to rule likewise that consular rights are human rights. The US responded that they are neither human rights nor fundamental, ${ }^{90}$ to which Germany replied that human rights need not be natural rights, but can be based on positive law. ${ }^{91}$ The Court found it unnecessary to reach the question. ${ }^{92}$ If the issue of prejudice is presented in a future case, the ICJ may have cause to revisit this question.

\subsection{Scope of application: severe penalties}

Even while agreeing with the US that state obligations under the Convention do not depend on the gravity of the alleged crime, the ICJ added that "it does not follow therefrom that the remedies for a violation [...] must be identical in all circumstances." 93 Among the assurances requested by Germany were effective judicial remedies "[i]n particular in cases involving the death penalty, [...]." ${ }^{94}$ The Court required judicial remedies

87. See, generally, e.g., Standt v. City of New York, supra note 78, at 428-429.

88. E.g., Inter-American Court of Human Rights, Advisory Opinion OC-16/99, 1 October 1999, The Right to Information Concerning Consular Assistance Within the Framework of Guarantees of Due Process of Law, Concurring Opinion of Judge Garcia Ramirez, accessible at www.oas.org, at 2; but see Khan $v$. United Kingdom, supra note 81, and Schenck $v$. Switzerland, supra note 81 .

89. Inter-American Court of Human Rights, Advisory Opinion OC-16/99, id., at paras. 141.1, 141.2 and 141.6; see Cassel, supra note 1, at 852 and n. 5, 878.

90. Verbatim Record, 14 November 2000, CR 2000/29, M. Trechsel, paras. 6.1-6.32; 17 November 2000, CR 2000/31, M. Trechsel, paras. 6.1-6.9.

91. Verbatim Record, 16 November 2000, CR 2000/30, M. Simma, paras. III.5-12.

92. Judgment, paras. 78, 126.

93. Id., at para. 63. Separately President Guillaume wrote that the Court's requirement of review of convictions and penalties

does not address the position [...] of individuals sentenced to penalties that are not of a severe nature. However, in order to avoid any ambiguity, it should be made clear that there can be no question of applying an a contrario interpretation [...].

Declaration of President Guillaume. If this means that even light penalties must be judicially reviewed and reconsidered in light of Convention violations, it is not clear that the full Court agrees.

94. Judgment, para. 120. 
"in cases where the individuals concerned have been subjected to prolonged detention or convicted and sentenced to severe penalties." 95

But what penalties are "severe"? Plainly they are not limited to the death penalty, since the Court also required judicial remedies for "prolonged detention." But how long must a detention be to qualify as "prolonged"? And how long a prison sentence amounts to a "severe" penalty? The ICJ Judgment treats imprisonment for two years as a "relatively light" penalty. ${ }^{96}$ Beyond that, how many years amount to "severe" imprisonment, requiring judicial remedies? National courts are left to interpret these questions for themselves, at least until the ICJ next has occasion (if ever) to clarify.

\section{ICJ Institutional Credibility}

The Judgment in Germany v. US is important not only for criminal justice and consular rights, but also for the ICJ's institutional credibility. In this author's view, the Court got it right. On the one hand, it refused to be cowed by exaggerated objections that it was being asked to intrude into domestic judicial administration in sensitive criminal matters; it properly answered that it was merely doing its job of interpreting and applying international law.

On the other hand, the Court went no further than justified by the facts of the case. It addressed the issues of individual rights and procedural default squarely raised by the case, without venturing into other issues not directly presented. It also got right the balance between national sovereignty and international supervision, ordering a remedy of result domestic review and reconsideration of convictions and sentences without intruding into the choice of means by which a state might meet its international obligations (at least until some future showing that a state might have failed to provide any adequate means).

And the Court did all this following a fully adversarial and deliberate proceeding, ${ }^{97}$ through an opinion attentive to the arguments advanced by

95. Id., at para. 125 .

96. The US cited cases where US nationals had been sentenced to "imprisonment" by German courts without being notified of their consular rights, yet Germany offered only an apology. Verbatim Record, 14 November 2000, CR 2000/28, M. Meron, paras. 3.46 and n. 77. In one case, for example, the sentence was for imprisonment of two years and four months. US Ex. 10. The ICJ described these sentences as "relatively light criminal penalties" which did not require the same remedies as "severe" penalties. Judgment, para. 63.

97. The Judgment thus contrasts with the earlier order indicating provisional measures. See Cassel, supra note 1 , at 886-887. 
both sides, transparently reasoned, ${ }^{98}$ and supported by strong majorities. ${ }^{99}$ The Judgment should thus serve to reinforce the Court's institutional credibility and effectiveness. ${ }^{100}$

One aspect of the Judgment may be a two-edged sword. It requires judicial review of violations not only in capital cases like the LaGrand case, but also in other cases of "severe penalties." The Court thus distances itself from the politically explosive issue of capital punishment, while also muting any concern that it targets the US because of the frequent use of the death penalty in that country.

On the other hand, the practical result is to increase the Court's exposure to potential controversy with the far greater number of states that do not use the death penalty, but do impose other severe penalties. Still, the burden on states to provide consular notice is not a heavy one. And for every receiving state reluctant to allow judicial review, there is a home state of the foreign national, which may well be grateful that its national has access to judicial review. From the standpoint of the Court as an institution, the net balance appears positive.

For the "big picture" of human rights, the Judgment is also a small but significant advance. The ICJ is not yet (and may never be) in the business of reviewing how domestic criminal justice systems respect the internationally recognized rights of their own citizens. But it has taken a precursor step by reviewing how they respect the rights of foreign nationals. Moreover, it has done so in the case of a powerful country which otherwise has yet to accept any binding mechanism of international human rights supervision. Whether consular rights be considered human rights (as the Inter-American Court of Human Rights has ruled) or at least individual rights (as the ICJ has ruled), that is a welcome step forward for the international rule of law.

98. The Court's articulation of reasoning on some specific points is summary, bordering on conclusory. This can be understood, however, to reflect the need to produce an opinion which can be supported by a court of 15 judges from diverse legal systems and backgrounds, and to minimize needless disagreements over details that do not alter the outcome. Even so, the Court's reasoning is clear enough to enable a state party to know that its arguments have been considered, and whether they have been accepted or rejected, and why, as well as the basic reasons that underlie the Court's principal conclusions.

From the perspective of common law lawyers, the Court's relative abstention from discussion of prior relevant cases is also frustrating. But this, too, is understandable, not only as a way to build convincing majorities on a large court, but more important, because many of the judges are not from common law systems.

99. Of the published votes in the case, one was unanimous, six were by 14-1, two by 13-2 and one by 12-3. Judgment, para. 128.

100. In dissent, Judge Oda wrote,

I very much fear that the Court's acceptance of this Application presented unilaterally pursuant to the 'optional clause' will in future lead States that have accepted the compulsory jurisdiction of the Court, $[\ldots]$, to withdraw their acceptance $[\ldots]$.

Dissenting Opinion of Judge Oda, para. 10. While only time will tell, this author does not share that opinion. 
Reproduced with permission of the copyright owner. Further reproduction prohibited without permission. 